\title{
PELAKSANAAN PROSEDUR PROTOKOLER COVID-19DALAM MELAYANI TAMU DISUSHI TEI RESTORAN DI MEDAN SUMATERA UTARA
}

Nirwaty Tarigan, Naomi Serlina Agave

E-mail : unint81@gmail.com

Tourism and Hotel Academy of Darma Agung

\begin{abstract}
Abstrak
Seluruh perusahaan yang bergerak dibidang food and beverage khususnya Sushi Tei Restoran diharuskan untuk memiliki prosedur khusus dalam hal penanganan pengolahan, penyajian maupun pelayanan makanan dan minuman kepada customer ditengah wabah COVID-19ini, hal ini berguna untuk menciptakan perasaan nyaman dan aman bagi customer yang akan membeli produk dari restoran tersebut, prosedur tersebut harus dapat dijalankan secara konsisten dan baik. Adapun yang menjadi fokus penelitian ialah prosedur khusus yang digunakan dalam melayani tamu. Penelitian ini dilakukan untuk mengetahui prosedur protokoler COVID-19 dalam melayani tamu di Sushi Tei Restoran di Medan Sumatera Utara, mengetahui jarak tempat duduk antara tamu yang satu dengan lainnya dan adakah pembatas atau partisiantar meja sesuai dengan protokol kesehatan untuk restoran yang dikeluarkan Menteri Kesehatan Republik Indonesia. Penelitian dilakukan dari tanggal 1 Mei 2020 sampai dengan 30 Juni 2020. yang menjadi populasi dalam penelitian ini adalah Cashier sebanyak 3 Orang, Greeter sebanyak 2 Orang, Pramusaji sebanyak 8 Orang,dan Bushboy sebanyak 1 Orang, sehingga sampel dalam penelitian ini sebanyak 14 orang. Dari hasil kesimpulan, maka penulis memberikan saran yang nantinya bisa menjadi bahan pertimbangan bagi restoran, agar kualitas pelayanan Sushi Tei Restoran dapat tetap terjaga.
\end{abstract}

Keywords: Prosedur Protokoler COVID-19, Pramusaji, Pelayanan Restoran.

\section{Pendahuluan}

Pada awal tahun 2020 dunia digemparkan dengan merebaknya wabah Coronavirus dengan jenis baru (SARS-CoV-2). Pada desember 2019 seorang pasien didiagnosis menderita pneumonia yang tidak biasa, pada 31 desember 2019 kantor regional organisasi kesehatan dunia (WHO) di Beijing telah menerima pemberitahuan tentang sekelompok pasien dengan pneumonia yang tidak diketahui penyebabnya dari kota yang sama yaitu Wuhan.Sampel isolat dari pasien diteliti dengan hasil menunjukkan adanya infeksi coronavirus, jenis betacoronavirus tipe baru, diberi nama 2019 novel Coronavirus (2019-nCoV).

Ini merupakan fenomena luar biasa yang terjadi di bumi pada abad ke 21. saat ini sudah dipastikan terdapat 65 negara yang telah terjangkit virus satu ini. (Data WHO, 1 Maret 2020).

Kasus COVID-19 pertama dilaporkan di Indonesia pada tanggal 2 Maret 2020 sejumlah dua kasus.Data 31 Maret 2020 menunjukkan kasus yang terkonfirmasi berjumlah 1.528 kasus dan 136 kasus kematian. Tingkat mortalitas COVID-19 di Indonesia sebesar 8,9\%, angka ini merupakan yang tertinggi di Asia Tenggara.

Menanggapi kasus COVID-19 ini pada tanggal 15 Maret 2020 melalui konferensi pers di Istana Bogor Presiden Republik Indonesia Joko Widodo menghimbau agar masyarakat bekerja,sekolah dan beribadah di rumah demi mencegah meluasnya penyebaran virus corona di Indonesia, 
pada tanggal 16 Maret 2020 Menteri kesehatan Republik Indonesia mengeluarkan surat edaran dengan nomor HK.02.01/MENKES/202/2020 tentang Protokol Isolasi Diri Sendiri dalam Penanganan Coronavirus Disease (COVID-19). Pada tanggal 17 Maret 2020 Menteri Pendidikan dan Kebudayaan Republik Indonesia mengeluarkan surat edaran dengan nomor 36962/MPK.A/HK/2020 tentang Pembelajaran Secara Daring dan Bekerja dari Rumah dalam Rangka Pencegahan Penyebaran Coronavirus Disease (COVID-19). Dengan diberlakukan Social distancing,Work from home dan pembelajaran secara daring, masyarakat dituntut untuk tidak melakukan akitivitas diluar rumah, menjauhi keramaian dan harus memperhatikan kebersihan serta pola hidup sehat unuk mengurangi penyebaranCOVID-19hal ini sangat berdampak dalam segala sektor terutama sektor pariwisata, salah satu usaha yang bergerak di sektor pariwisata yang paling terkena dampak wabah COVID-19 ini ialah Restoran terlihat dari penurunan jumlah customer yang datang setelah adanya wabah COVID-19 karena saat inibanyak masyarakat yang memilih mengolah makanan untuk kebutuhan sehari-hari di rumah dengan alasan keamanan, kenyamanan, dan mengurangi kontak langsung dengan banyak orang ditengah wabah COVID-19 ini,tetapi tidak sedikit dari masyarakat yang masih memilih untuk memesan makanan dari berbagai restoran untuk memenuhi kebutuhan pangan sehari-hari.

Ditengah wabah COVID-19 ini seluruh perusahaan yang bergerak dibidang food and beveragekhususnya Sushi Tei Restoran diharuskan untuk memiliki prosedur khusus dalam hal penanganan pengolahan, penyajian maupun pelayanan makanan dan minuman kepada customer untuk menciptakan perasaan nyaman dan aman bagi customer yang akan membeli produk dari restoran tersebut,prosedur tersebut harus dapat dijalankan secara konsisten dan baik, apabila tidak dijalankan dengan baik maka akan menimbulkan rasa tidak percaya customer terhadap restoran tersebut sehingga dapat membuat citra kurang baik bagi customer untuk datang kembali.

\section{Perumusan Masalah}

Masalah yang dirumuskan adalah sebagai berikut:

1. Bagaimana Prosedur protokoler COVID-19 dalam melayani tamu di Sushi Tei Restoran di Medan Sumatera Utara?

2. Bagaimana Jarak tempat duduk antara tamu yang satu dengan lainnya di Sushi Tei Restoran Manhattan di Medan Sumatera Utara?

3. AdakahPembatas atau Partisi antar meja pada Sushi Tei Restoran Manhattan Medan Sumatera Utara?

\section{Tujuan Penelitian}

Tujuan penelituan berdasarkan perumusan masalah tersebut diatas adalah:

1. Untuk mengetahui prosedur protokoler COVID-19 dalam melayani tamu di Sushi Tei Restoran di Medan Sumatera Utara

2. Untuk mengetahui Jarak tempat duduk antara tamu yang satu dengan lainnya di Sushi Tei Restoran Manhattan di Medan Sumatera Utara.

3. Untuk mengetahui adanya Pembatas atau Partisi antar meja pada Sushi Tei Restoran Manhattan Medan Sumatera Utara. 


\section{Kerangka Konsep}

\section{Pengertian Prosedur}

Menurut Seprida Hanum Harahap, Wahyudi dan Surya Sanjaya (2015:167) Prosedur merupakan rangkaian kegiatan yang saling berhubungan satu dengan lainnya, prosedur biasanya melibatkan beberapa orang dalam suatu departemen. Prosedur adalah paduan untuk rangkaian kegiatan yang saling berhubungan melibatkan beberapa orang untuk menjamin kegiatan yang berulang secara seragamdan efisien tanpa ada penyimpangan.

\section{Pengertian Protokoler}

Menurut Kamus Besar Bahasa Indonesia (KBBI) Protokoler ialah berhubungan dengan protokol; bersifat keprotokolan dan Menurut Asti Musman (2020:7) Protokol berisi pedoman atau tata cara suatu kegiatan. Semua hal yang mengatur pelaksanaan suatu kegiatan disebut Protokoler.

Dari pengertian dapat disimpulkan bahwa Protokolermemiliki arti yang sama dengan Protokol ialah tata cara atau pedoman dalam mengatur pelaksanaan sebuah kegiatan.

\section{COVID-19}

Menurut Zhang Wenhong (2020:3) Virus ini diduga menyebar terutama dari orang ke orang melalui droplet (percikan cairan tubuh) dari saluran pernapasan yang terpercik ketika seorang sudah terinfeksi batuk atau bersin. Droplet tersebut dapat mendarat di mulut atau hidung orang yang berada didekatnya atau mungkin terhirup kedalam paru-paru. Ada juga kemungkinan bahwa seseorang dapat terkena COVID-19 dengan menyentuh permukaan atau barang dimana ada virus menempel, dan kemudian menyentuh mulut,hidung, atau mungkin matanya. Risiko terkena COVID-19 dari tinja seseorang yang terinfeksi atau melalui udara tampaknya rendah. Masa inkubasi COVID-19 (yaitu waktu antara sejak terpapar virus sampai timbulnya gejala) saat ini diperkirakan antara 1-14 hari dan sebagian besar antara 3-7 hari.

Gejala COVID-19yang paling umum adalah demam,kelelahan dan batuk kering. Sebagian pasien mungkin menderita sakit dan nyeri dibagian tubuh, hidung tersumbat, pilek atau diare. Sebagian lainnya hanya mengalami gejala ringan seperti demam ringan, dan lain-lain. Sekitar 1 dari 6 orang yang terkena COVID-19 menjadi sakit parah dan mengalami kesulitan bernapas setelah terinfeksi selama satu minggu.

\section{Pengertian Pramusaji}

Menurut Marsum WA (2018:90)Pramusaji ialah karyawan/karyawati di dalam sebuah restoran yang bertugas menunggu tamutamu, membuat tamu- tamu merasa mendapat sambutan dengan baik dan nyaman, mengambil pesanan makanan dan minuman serta menyajikannya, juga membersihkan restoran dan lingkungannya serta mempersiapkan meja makan (table setting) untuk tamu berikutnya.

\section{Pengertian Pelayanan}

Menurut Dr. Kasmir, S.E., M.M (2019:47) Pelayanan diartikan sebagai tindakan atau perbuatan seseorang atau organisasi untuk memberikan kepuasan kepada pelanggan atau sesama karyawan.

Menurut Marsum WA (2018:273) Pelayanan itu adalah SERVICE ( Smile for Every one, Excellent in everything we do, Reaching out to every guest with hospitality, Viewing every guests as special, Inviting guests to return, Creating a warm 
atmosphere, Eye contact that shows we are.

\section{Pengertian Restoran}

Menurut Marsum WA (2018:7) Restoran adalah suatu tempat atau bangunan yang diorganisasi secara komersial, yang menyelenggarakan pelayanan dengan baik kepada semua tamunya baik berupa makan maupun minuman

\section{Metodologi}

\section{Lokasi dan Waktu Penelitian}

Penelitian ini dilaksanakan di restoran Sushi Tei Medan cabang Manhattan Times Square, Jalan Gatot Subroto No.217, Sei Sikambing B, Kecamatan Medan Sunggal, Kota Medan, Sumatera Utara, 20123. Nomor telepon (061)62001105.Adapun waktu penelitian dilaksanakan pada $1 \mathrm{Mei}$ 2020 sampai dengan 30 Juni 2020 di Sushi Tei Medan cabang Manhattan Times Square.

\section{Populasi}

Populasi adalah wilayah generalisasi terdiri dari atas objek dan subjek yang mempunyai kualitas dan karakteristik tertentu yang ditetapkan oleh peneliti untuk dipelajari dan kemudian ditarik kesimpulannya. Yang menjadi populasi dalam penelitian ini adalah Cashier sebanyak 3 Orang, Greeter sebanyak 2 Orang, Pramusaji sebanyak 8 Orang,dan Bushboy sebanyak 1 Orang pada Sushi Tei Restoran di cabang Manhattan Times Square Medan Sumatera Utara.

\section{Sampel}

Sampel adalah bagian dari jumlah karakteristik yang dimiliki populasi, Apabila subjek kurang dari 100 orang maka lebih baik diambil keseluruhannya sebagai sampel dalam penelitian ini, sehingga sampel dalam penelitian ini sebanyak 14 orang.

\section{Metode Pengumpulan Data}

1. Library Research (penelitian kepustakaan)

Penelitian yang dilakukan melalui perpustakaan yaitu buku-buku yang berhubungan dengan topik yang dibahas.

2. Field Research (penelitian lapangan)

Penelitian yang dilakukan secara langsung ke objek yang akan diteliti untuk mendapatkan data-data yang dibutuhkan melalui wawancara observasi penelitian.

\section{Sejarah Berdirinya Sushi Tei Restoran Medan}

Restoran Sushi Tei adalah salah satu restoran halal yang menyediakan jenis jenis makanan dan minuman khas Jepang. Restoran ini franchise dari Jakarta yang pertama sekali diperkenalkan di Medan pada tanggal 05 Januari 2005 dengan outlet pertamanya di Jalan Teuku Daud no 6/12 Medan dibawah naungan PT Bisa Group.Kemudian dengan jumlah tamu yang semakin meningkat, akhirnya cabang dibukadi beberapa mall yang sedang berkembang di kota Medan. Sushi Tei Medan berada di 6 cabang.

\section{ANALISIS MASALAH}

1. Prosedur protokoler COVID-19 dalam melayani tamu di Sushi Tei Restoran di Medan Sumatera Utara

Menyikapi wabah COVID-19 ini perusahaan yang bergerak dibidang food and beverage khususnya Sushi Tei Restoran diharuskan untuk memiliki prosedur khusus dalam hal penanganan pengolahan, penyajian maupun pelayanan makanan dan minuman kepada tamu untuk menciptakan perasaan nyaman dan aman bagi tamu yang akan membeli produk dari 
restoran tersebut, prosedur tersebut harus dapat dijalankan secara konsisten dan baik. Adapun prosedur protokoler COVID-19 dalam melayani tamu yang diterapkan di Sushi Tei Restoran ialah:

\section{1) Greeting}

Greeter mengucapkan salam kepada tamu sesuai dengan waktu:Konichiwa untuk Selamat Siang dan Konbanwa untuk selamat malam.lalu greeter meminta izin kepada tamu untuk mengecek suhu tubuh beliau menggunakan thermometer sensor dengan jarak $30 \mathrm{~cm}$ dan tamu wajib berdiri pada garis yang sudah ditentukan, mengarahkan tamu untuk memakai hand sanitizer yang disediakan dan menawarkan tamusarung tangan plastik apabila diperlukan.

\section{2) Taking Order}

Setelah tamu duduk, greetermemberikan menu digital dalam bentuk barcode kepada tamu, pramusaji yang bertugas di area meja tersebut langsung mendatangi tamu menyebutkan salam sesuai waktu, nama dan menjelaskan mekanisme cara order makanan melalui barcode tersebut, apabila ponsel tamutidak bisa scan barcode,tamu diarahkan untuk mengakses link yang sudah disediakan, tetapi apabila ponseltamu juga tidak bisa atau tamu mengalami kesulitan dalam mengorder melalui barcode atau linktamu akan diberikan buku menu. Sebelum memberikan buku menu greeter wajib mensanitasi ulang buku menu tersebut.

\section{3) Sugesstive and Upselling}

Setelah tamu sudah dijelaskan prosedur pengorderan menggunakan barcode, pramusaji menawarkan menu favorite, dessert atau menu promo secara singkat kepada tamu guna menjaga kenyamanan tamu dan menginfokan kepada tamu dapat memanggil pramusaji apabila membutuhkan bantuansecara langsung atau dengan menekan tombol syscall yang tersedia meja tertentu.

\section{4) Repeat order}

Setelah tamu selesai order dan menekan tombol bayar pada link tersebut maka orderan tamu tersebut otomatis masuk ke sistem Ezo yang ada di Tablet Sushi Tei maka pramusajiharus mengulang atau menyebutkan kembali pesanan tamu tersebut sesuai dengan yang ditampilkan pada Tablet tersebut sebelum diiput ke sistem POS (Point of Sales) Sushi Tei yang bertujuan menghindari kesalahan dalam penginputan makanan atau minuman tamu.

\section{5) Ordering}

Pramusaji menginput makanan dan minuman tamu sesuai dengan request tamu ke POS (Point of Sales) sehingga makanan dan minuman tamu dapat diproses segera oleh pihak dapur dan bar.Food checker ditempelkan di area sectionfood runner guna mempercepat proses follow up makanan tamu ke dapur.

\section{6) Adjusment and delivery order}

Peralatan makan tamu disediakan pramusajisesuai dengan pesanan tamu contohnya apabila tamu memesan nasi maka diberikan dinner spoon dan dinner fork yang di alasi dengan tisu, apabila tamu memesan noodle maka wajib disediakan sharing bowl dan duck spoon sesuai dengan pax tamu. Pada saat makanan tamu tersaji dari dapur pramusaji yang bertugas di area Food runner harus mencoret nama menu tersebut pada food checker tersebut dan menuliskan jam keluar makanan tersebut yang menandakan bahwa menu tersebut sudah selesai diproses agar tidak terjadi double follow up ke pihak dapur sehingga product tidak dibuat ulang. 


\section{7) Last checking}

Mengecek ulang seluruh makanan dan minuman tamu apakah sudah tersaji seluruhnya secara baik, tidak lupa menanyakan secara singkat kepada tamu apakah ada saran atau kendala terkait pelayanan atau makanan yang disajikan.

\section{8) Refill ocha and Prebushing}

Mengisi ulang ocha (teh hijau) ke gelas tamu apabila sudah tinggal setengah gelas dan mengangkat piring tamu yang sudah selesai di gunakan.

\section{9) Offerring Dessert and Take away}

Menawarkan kembali kepada tamu dessert dan take away yang berguna untuk meningkatkan penjualan.

\section{0) Billing}

Memberikan bill kepada tamu dengan posisi bill holder dalam posisi terbuka dan menyebutkan promo bank yang berlangsung. Setelah tamu pulang, meja dibersihkan dan disanitasi kembali, condiment, tencard, kotak tisu kembali disanitasi dan disimpan ke service section, meja harus kembali dalam keadaan kosong, Napkin yang digunakan untuk sanitasi dan clear up harus dipisahkan.

\section{Gambar 1}

Alur pelaksanaan prosedur protokoler Covid-19 dalam melayani tamu di Sushi Tei Restoran di Medan Sumatera Utara

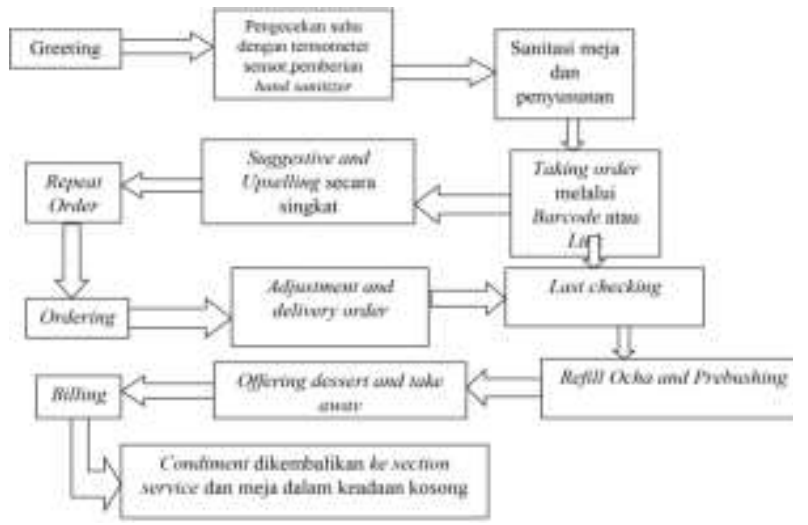

\section{Sumber : Sushi Tei Restoran}

Manhattan, 2020

Dari bagan diatas terlihat perbedaan prosedur yang terbaru dengan prosedur sebelumnya yaitu perubahan urutan sebelumnya setelah greeting step selanjutnya suggestive and upselling sekarang berubah menjadi taking order. Ada beberapa penambahan seperti pada saat tamu datang wajib dilakukan pengecekan suhu, pemberian hand sanitizer, meja disanitasi kembali, pemberian wadah berisi air panas untuk perendaman cutteleries yang akan digunakan tamu, pengorderan dengan menu digital, dan meja yang tidak di setting kembali setelah tamu pulang.

Dalam pelaksanaan prosedur terbaru ini Sushi Tei Restoran juga mengalami beberapa kendala yang menyebabkan operasional tidak berjalan dengan lancar, Pramusaji terkadang melewatkan beberapa langkah dari prosedur yang diterapkan seperti :

1. Pramusaji sering lupa untuk repeat order dimana dengan metode pengorderan terbaru ini masih banyak tamu yang kurang paham dengan detail menu yang beliau pesan melalui link atau barcode.

2. Pramusaji incharge terkadang lupa memberikan Sharing bowl dan duck spoon apabila tamu memesan ramen atau udon sehingga tamu harus menunggu peralatan makan yang beliau butuhkan untuk mengonsumsi makanannya.

3. Pramusaji jarang melakukan prebushing sehingga tamu terkadang kesulitan apabila hidangan selanjutnya datang dikarenakan mejanya sudah penuh dengan wadah makanan yang sudah selesai ia konsumsi. 
4. Pramusaji yang bertugas diarea food runner sering terlupa dalam mencoret nama makanan pada food checker yang sudah dikeluarkan dari dapur sehingga seringkali terjadi double follow up makanan tamu ke pihak dapur dan menyebabkan product diproses kembali padahal makanan tersebut sudah di konsumsi oleh tamu.

Adapun sebelum diterapkannya prosedur terbaru ini karyawan sudah diberikan pelatihan berikut adalah data karyawan yang sudah mengikuti pelatihan:

\section{Tabel 1}

Data Karyawan Yang Mengikuti Training Mengenai Prosedur Protokoler Covid-19 Dalam Melayani Tamu

\begin{tabular}{|l|l|l|l|}
\hline No & $\begin{array}{l}\text { Jawaban } \\
\text { Informan }\end{array}$ & Jumlah & $\begin{array}{l}\text { Persentase } \\
(\%)\end{array}$ \\
\hline 1 & $\begin{array}{l}\text { Sudah } \\
\text { Pelatihan }\end{array}$ & 10 & 71 \\
\hline 2 & $\begin{array}{l}\text { Belum } \\
\text { Pelatihan }\end{array}$ & 4 & 29 \\
\hline \multicolumn{2}{|l}{ Total } & 14 & 100 \\
\hline
\end{tabular}

Sumber : Olahan Data Karyawan Sushi Tei Restoran Manhattan, 2020

Dari tabel diatas dapat disimpulkan bahwa masih ada karyawansebanyak $29 \%$ yang belum mengikuti training atau pelatihan mengenai prosedur protokoler COVID-19 hal ini menyebabkan beberapa pramusaji masih belum paham dengan prosedur yang berlaku sekarang sehingga prosedur masih belum berjalan dengan sempurna di operasional sehingga pelayanan yang diberikan kepada tamu masih kurang maksimal.

Tabel 2

Tingkat Pemahaman Karyawan Dalam

Melaksanakan Prosedur Protokoler

Covid-19 Dalam Melayani Tamu

\begin{tabular}{|l|l|l|l|}
\hline No & Jawaban & Jumlah & Persentase \\
\hline
\end{tabular}

\begin{tabular}{|l|l|l|l|}
\hline & Informan & & $\mathbf{( \% )}$ \\
\hline 1 & Paham & 9 & 64 \\
\hline 2 & $\begin{array}{l}\text { Kurang } \\
\text { Paham }\end{array}$ & 3 & 22 \\
\hline 3 & $\begin{array}{l}\text { Tidak } \\
\text { Paham }\end{array}$ & 2 & 14 \\
\hline \multicolumn{2}{|l|}{ Total } & 14 & 100 \\
\hline
\end{tabular}

Sumber : Olahan Data Karyawan Sushi Tei Restoran Manhattan, 2020

Dari tabel diatas dapat dilihat bahwa hanya $64 \%$ pramusaji yang paham dan mampu melaksanakan pelayanan sesuai dengan prosedur yang diterapkan dengan baik, hal ini menyebabkan pelayanan yang diberikan kepada tamu kurang maksimal sehingga dalam pelaksanaannya dapat disimpulkan prosedur protokoler COVID-19 dalam melayani tamu di Sushi Tei terkhusus cabang Manhattan belum sepenuhnya terlaksana dengan baik.

\section{Jarak tempat duduk antara tamu} yang satu dengan lainnya di Sushi Tei Restoran Manhattan di Medan Sumatera Utara.

Menteri Kesehatan Republik Indonesia mengeluarkan surat edaran dengan nomor HK.01.07/MENKES/382/2020 tentang Protokol Kesehatan bagi masyarakat di tempat dan fasilitas umum dalam rangka pencegahan dan pengendalian Corona Virus Disease 2019 (COVID-19), restoran wajib menerapkan protokol kesehatan yang ketat, antara lain:

1) Memperhatikan informasi terkini serta himbauan dan instruksipemerintah pusat dan pemerintah daerah terkait COVID19 diwilayahnya.

2) Menyediakan sarana cuci tangan pakai sabun atauhandsanitizer di pintu masukdan tempat lain yang mudahdiakses pengunjung. 
3) Mewajibkan setiap orang yang akan masuk untuk mencucitangan pakai sabun dengan air mengalir atau menggunakanhandsanitizer.

4) Mewajibkan pekerja menggunakan masker selama bekerja.

5) Pastikan pekerja memahami COVID-19 dan cara pencegahannya.

6) Larangan masuk bagi pekerja dan pengunjung yang memilikigejala demam, batuk, pilek, nyeri tenggorokan, sesak nafas,dan/atau diare atau memiliki riwayat kontak dengan orangterkena COVID-19.

7) Melakukan pemeriksaan suhu tubuh di pintu masuk. Jikaditemukan pekerja atau pengunjung dengan suhu $>37,3^{\circ} \mathrm{C}$ (2kali pemeriksaan dengan jarak 5 menit) tidak diperkenankanmasuk.

8) Mewajibkan semua penjamah pangan atau pekerja yang kontaklangsung dengan pangan agar mengenakan masker, sarung tangan, atau penjepit pada saat menyentuh pangan siap saji dan mengenakan penutup kepala dan celemek pada saat persiapan, pengolahan, dan penyajian pangan. Penggunaan sarung tangansesuai dengan standar keamanan pangan yang berlaku.

9) Menyediakan alat bantu seperti sarung tangan dan/ataupenjepit pangan untuk meminimalkan kontak langsung dengan pangan siap saji dalam proses persiapan, pengolahan, dan penyajian.

10) Tidak menerapkan sistem prasmanan/buffet.

11) Menjaga kualitas udara di tempat usaha atau di tempat kerjadengan mengoptimalkan sirkulasi udara dan sinar matahari masuk serta pembersihan filter AC.

12) Mengupayakanpembayaran secara nontunai

(cashless)dengan memperhatikan disinfeksi untuk mesin pembayaran. Jika harusbertransaksi dengan uang tunai, gunakan handsanitizersetelahnya.

13) Memastikan seluruh lingkungan restoran/rumah makan dalam kondisi bersihdan saniter dengan melakukan pembersihan dandisinfeksi secara berkala minimal 2 kali sehari (saat sebelumbuka dan tutup) menggunakan pembersih dan disinfektan yang sesuai.

14) Meningkatkan frekuensi pembersihan dan disinfeksi (palingsedikit 3 kali sehari) terutama pada permukaan area dan peralatan yang sering disentuh/dilewati orang seperti meja dan kursi di ruang makan, kenop/gagang pintu, sakelar, kran, tuas flush toilet, toilet, meja kasir, mesin penghitung uang/kasir, lantai ruang makan, dan lain lain.

15) Menutup alat makan yang diletakkan di meja makan (sendok,garpu, pisau dibungkus misalnya dengan tissue). Tidak menggunakan alat makan bersamasama.

16) Menerapkan jaga jarak dengan berbagai cara seperti:

- Mengatur jarak minimal 1 meter pada saat antri masuk rumah makan/restoran dan sejenisnya, memesan, dan membayar di kasir dengan memberikan tanda di lantai.

- Pengaturan jarak antar kursi minimal 1 meter dan 
tidak saling berhadapan atau pemasangan

partisi kaca/mika/plastik antar tamu di atas meja makan.

17) Meningkatkan

pemesanan

minumansecara makanan dan delivery service atau drive thru, dan lain sebagainya.

Sesuai dengan ketentuan nomor 17 pada surat edaran tersebut di point 2 restoran wajib mengatur jarak antar kursi minimal 1 meter, pengaturan jarak tempat duduk antara tamu yang satu dengan lainnya tidak terlihat secara simbolik di Sushi Tei Restoran dikarenakan tidak diberikannya tanda $X$ pada sofa maupun kursi di restoran tersebut dimana yang diperbolehkan saat ini meja digunakan hanya setengah kapasitas seharusnya,walaupun tidak diberikan tanda pada sofa atau kursi, mengenai pengaturan jarak dan pembatasan pax per mejatetap disampaikan secara lisan oleh Greeter saat hendak mengantar tamu ke mejanya. Walaupun greeter sudah menyampaikan perihal pengaturan jarak dan pembatasan pax per mejanya tetap saja masih ada beberapa tamu grup yang enggan untuk mejanya dipisah dengan berbagai alasan seperti sulitnya berkomunikasi atau kesulitan saat hendak meeting.

\section{Pembatas atau Partisi antar meja pada Sushi Tei Restoran Manhattan Medan Sumatera Utara.}

Sesuai dengan ketentuan nomor 16 pada surat edaran tersebut di point 2 perihal pemasangan partisi kaca atau mika atau plastik antar tamu, hal ini juga masih belum terealisasi di Sushi Tei Restoran cabang Manhattan karna masih dalam proses perencanaan sehingga meja pada Sushi Tei Restoran sampai saat ini masih belum memiliki partisi. Adapun dari hasil wawancara penulis dengan supervisor restoran setiap meja pada Sushi Tei Restoran direncanakan akan diberikan partisi akrilik adapun tujuan pemasangan partisi akrilik bertujuan untuk menjaga jarak tamu yang satu dengan lainnya sehingga kenyamanan tamu saat dine in tetap terjaga.

\section{KESIMPULAN DAN SARAN}

\section{Kesimpulan}

Bedasarkan pembahasan yang telah diuraikan pada bab-bab sebelumya penulis dapat mengambil kesimpulan sebagai berikut :

1. Pelaksanaan prosedur protokoler COVID-19dalam melayani tamu di Sushi Tei Restoran Medan cabang Manhattan belum sepenuhnya terlaksana dengan baik, dikarenakan beberapa pramusaji masih belum menjalankan sesuai dengan prosedur yang ditetapkan hal ini disebabkan kurangnya pelatihan mengenai prosedur terbaru bahkan masih ada karyawan yang belum mengikuti pelatihan mengenai prosedur terbaru ini sehingga beberapa pramusajimasih ada yang kurang paham dalam melaksanakan prosedur terbaru ini.

2. Pengaturan jarak tempat duduk antara tamu yang satu dengan lainnya tidak terlihat secara simbolik di Sushi Tei Restoran Manhattan dikarenakan tidak diberikannya tanda $\mathrm{X}$ pada sofa maupun kursi di restoran tersebut dimana yang diperbolehkan saat ini meja digunakan hanya setengah kapasitas dan pengaturan jarak hanya diinfokan melalui lisan oleh greeter.

3. Belum ada partisi antar meja pada Sushi Tei Restoran Manhattan 
Medan yang bertujuan untuk menjaga jarak tamu yang satu dengan lainnya dalam satu meja.

\section{Saran}

Berdasarkan pembahasan yang telah diuraikan pada babsebelumnya penulis membuat saran sebagai berikut:

1. Bagi Pramusaji yang tidak melaksakan prosedur pelayanan secara baik kepada tamu, sebaiknya diberi arahan kembali saat briefing.

2. Melaksanakan kembali training atau pelatihan mengenai prosedur terbaru ini kepada seluruh karyawan agar prosedur dapat dilaksanakan lebih baik dan pelayanan terbaik dapat diberikan kepada tamu.

3. Supervisor incharge wajib meningkatkan pengawasan dan melakukan evaluasi kinerja pramusaji dengan cara memperhatikan secara langsung saat pramusaji sedang melayani tamu.

4. Mengkaji ulang feedback dari tamu mengenai prosedur terbaru yang dijalankan yang berguna untuk meningkatkan mutu pelayanan di Sushi Tei Restoran.

5. Pemberian tanda $X$ pada sofa maupun kursi pada Sushi Tei Restoran sehingga mempermudah pekerjaan greeterdalam hal edukasi tamu mengenai pengaturan jarak terutama pada tamu grup.

6. Merealisasikan pemasangan partisi antar meja tamu agar kenyamanan tamu tetap terjaga saat dine in.

\section{DAFTAR PUSTAKA}

Harahap, Seprida Hanum, Wahyudi dan Surya Sanjaya. 2015. Sistem Informasi Akuntansi. Bandung, Citapustaka Media
Kasmir, 2019. Customer Service Excellent Teori dan Praktik, Depok, PT Rajagrafindo Persada.

Musman, Asti, 2020.Cara-Cara Berbicara Didepan Umum, Menguasai Panggung dan Berpidato dalam Segala Suasana, Yogyakarta, Komunika.

Sailendra, Annie, 2015. Langkah-Langkah Praktis Membuat SOP Standard Operating Procedures, Yogyakarta, Trans Idea Publishing.

WA, Marsum, 2018. Restoran dan Segala Permasalahannya, Yogyakarta, Andi.

Wenhong, Zhang, 2020. Paduan Pencegahan dan Pengawasan COVID-19, Jakarta, Papas Sinar Sinanti. 


\begin{tabular}{|l|l|l|l|l|}
\hline Jurnal Akomodasi Agung & Vol -VI & NO.2 & Oktober 2020 & ISSN 2503- 2119 \\
\hline
\end{tabular}




\begin{tabular}{|l|l|l|l|l|}
\hline Jurnal Akomodasi Agung & Vol -VI & NO.2 & Oktober 2020 & ISSN 2503- 2119 \\
\hline
\end{tabular}

